\title{
INVESTIGATION OF THE EFFECTIVENESS OF AIR PASTEURIZATION OF SAUSAGE PRODUCTS USING ACTIVE PACKING ELEMENTS
}

\author{
Vasil Pasichnyi \\ Department of technology of meat and meat products \\ Educational and Research Institute of Food Technology \\ 68 Volodymyrska str., Kyiv, Ukraine, 01601 \\ Pasww1@ukr.net \\ Anatoliy Ukrainets \\ National University of Food Technology \\ 68 Volodymyrska str., Kyiv, Ukraine, 01601 \\ info@nuft.edu.ua \\ Oleg Khrapachov \\ Regional represantative LLC «Sirius Extrusion» \\ 20 Pilotskaya str., Khmelnitsky, Ukraine, 29010 \\ kov.pack@ukr.net \\ Andrii Marynin \\ Laboratory of Problem research \\ National University of Food Technologies \\ 68 Volodymyrska str., Kyiv, Ukraine, 01601 \\ andrii_marynin@ukr.net \\ Roman Svyatnenko \\ Laboratory of Problem research \\ National University of Food Technologies \\ 68 Volodymyrska str., Kyiv, Ukraine, 01601 \\ Svyatnenko@i.ua \\ Olena Moroz \\ Lviv College of Meat and Dairy Industry \\ 30/32 Bortnyansky str., Lviv, Ukraine, 79039 \\ olenaom@ukr.net
}

\footnotetext{
Abstract

The aim of the researches was to determine the effectiveness of repeated pasteurization using an air absorbent. The effectiveness of repeated pasteurization is studied at an air absorbent for prolonging the storage life of sausage products.

Pasteurization was realized at temperature $85-90{ }^{\circ} \mathrm{C}$ during $15-20$ minutes. The obtained results of the stability of quality indices of sausage products in storage terms up to 94 days corresponded to standard values for this product type.

According to organoleptic parameters, products correspond to requirements of normative documents and have high quality indices during the indicated storage term.

At the end of the storage term the deviation of the quality index of organoleptic parameters by the five-point scale was no more 0,09 units for pasteurized products with an air absorbent. The decrease of the index of the average point mark for pasteurized products without an air absorbent was 0,17 units. It proves the high stability of the quality of sausage products at the storage process.

The conducted analysis as to the change of the water activity index in storage terms for pasteurized wieners with an air absorbent proves that its use doesn't essentially influence aw value. This effect is proved by the microbiological and organoleptic stability of sausage products at storage.
}

Keywords: air absorbent, boiled sausage products, repeated pasteurization, water activity. Andrii Marynin, Roman Svyatnenko, Olena Moroz 


\section{Introduction}

Technologies of package and storage using active packing systems are effectively introduced in food industry [1]. For getting the high level of products protection there are used multi-layer polymer materials that can raise a barrier of protective films [2]. The type of packing materials in meat products is important for production stages and must provide the effectiveness for protecting products with different types of thermal processing [2, 3].

Storage of animal food products limits time possibilities of their realization in trade nets as a result of the presence of specific contaminant forms of microorganisms that can manifest their life activity in the wide diapason of temperatures $[4,5]$.

Today realities need to solve the complex of problems, directed on preserving the quality of food products and prolonging their storage terms.

One of ways of prolonging storage terms of sausage products is the use of repeated pasteurization, elements of active package [3, 4]. Multi-layer polymer materials that can provide conditions for repeated pasteurization and high barrier properties of materials are used at meat products manufacturing $[5,6]$.

The use of vacuum package doesn't allow to eliminate $\mathrm{O}_{2}$ from a packed product completely, that is why active elements that eliminate oxygen are used in storage technologies. One of such elements is an air absorbent, which work can be prolonged in time.

Important factors of storing quality and safety parameters of products are substantiations of storage methods [7]. Conservation by heating provides driving products to readiness using different types of thermal processing for meat products [8-10]. A series of researchers recommend to use complexes of natural antioxidants, present in spicy-aromatic raw materials, fruits and vegetables in the production process alongside with decreasing a level of microbiological contamination $[11,12]$. There are studies that prove the expedience of introducing extracts of black pepper [13, 14], oil resins of rosemary $[14,15]$, and also extracts of mace and coriander that have the bactericidal effect $[15,16]$ for achieving bacteriostatic effects.

One of important factors that characterize a possibility of storing food products is a water activity index $\mathrm{a}_{\mathrm{w}}[17,18]$. It allows to prognosticate the intensity of the development of contaminant forms of microorganisms in food products. Prognostication and search for ways of inhibiting the development of undesirable forms of microorganisms in products with using animal and vegetable raw materials need further studies $[18,19]$. Thus, realization of studies as to a possibility of the effective prolongation of storage terms of sausage products at using repeated pasteurization with active package elements is urgent and needs further studies.

The aim of the research is to reveal a possibility to prolong storage terms of sausage products of the boiled group at using repeated pasteurization and sachet-pack of an air absorbent.

\section{Materials and methods of investigating pasteurized sausage products with an air absorbent}

For studying a possibility of prolonging storage terms of boiled sausage products, there were used samples of wieners of the highest sort "Extra" and wieners "Tasty" of the first sort, produced at "Zhytomyr meat processing factory" LTD (Ukraine) according to TC U 15.1-32122069006:2008.

After finishing the technological process (cooling to temperature $15^{\circ} \mathrm{C}$ ), samples of wieners were packed in vacuum in multi-layer materials (films), produced by "Sirius Extrusion" (Ukraine). The number of packed wieners in one packing was 3-4 units, for three- and fourfold reiteration of the studied indices.

Samples were packed with and without sachet-packs of an air absorbent (Fig. 1) according to TC U 20.5-02070938-143:2013, made by "YUTAK" LTD (Ukraine).

The process of packing products before pasteurization was conducted on thermoforming lines of trademarks «Multivac» and «Webomatic», pasteurization - in a universal microchamber of TM «Fessman», made in Germany. Wieners were packed directly under production conditions of “Zhytomyr meat processing factory" LTD.

Repeated pasteurization with and without an air absorbent was conducted for packed wieners. 
Values of $\mathrm{a}_{\mathrm{w}}$ and moisture of wieners of the highest sort were determined at 35-th, 65-th and 94-th day of storage. The storage time included a reserve coefficient for guaranteeing the correspondence of storage terms, longer than 45 days.

During the storage term, there were analyzed organoleptic parameters of sausage products [20], moisture content in packed sausage products and also the water activity value $\left(\mathrm{a}_{\mathrm{w}}\right)$.

Water activity is one of main parameters of the conception of analysis of risks and critical control points (HACCP) that is a base system of providing the quality of food products in most developed countries of the world. $a_{w}$ for sausage products of the boiled group can be within $0,86-0,98$, depending of a recipe of this product [13].

$\mathrm{a}_{\mathrm{w}}$ value of wieners, subjected to different conditions of thermal processing (pasteurization with and without an air absorbent) was determined on a device Hygrolab-2 (Rotronic, Switzerland) at temperature $18-20{ }^{\circ} \mathrm{C}$ with measuring distinctness $1,5 \%, 0,3{ }^{\circ} \mathrm{C} 0,005$ un. $\mathrm{a}_{\mathrm{w}}+1.5 \%$ of the value (Fig. 1).

The water activity $a_{w}$ is expressed by values from 0,00 to 1,00 and characterizes the potential ability of products to spoilage. The less $a_{w}$ value, the higher its microbiological stability at storage is.

$a_{w}=1,00$ corresponds to distilled water and $a_{w}=0,00-$ to the condition of an absolutely dehydrated product.

The correspondence of the moisture content in wieners was determined according to TC C 15.1-32122069-006:2008 requirements.

The standard method of determining moisture by changing a sample mass in weighing bottle is used [20]. Experimental samples were dried in a drying chamber «MLW», Germany, Fig. 2, at temperature $150-155^{\circ} \mathrm{C}$ to the constant mass of a batch.

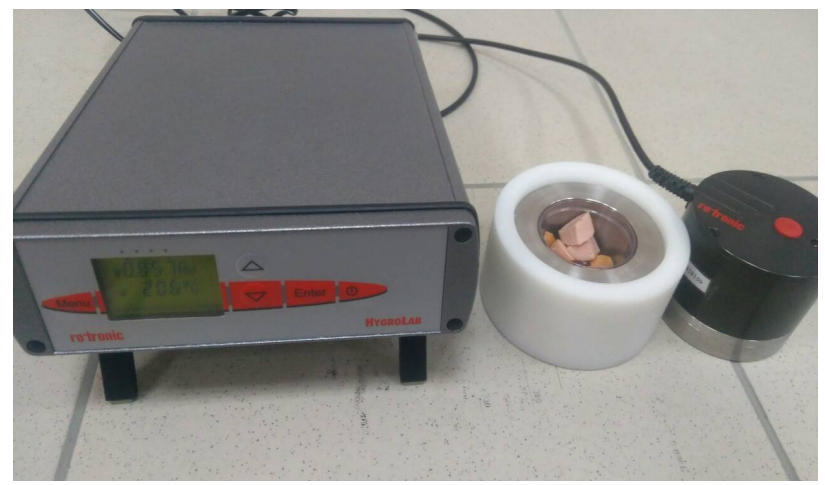

Fig. 1. Device Hygrolab-2 for determining the water activity

Indices of the water activity $\mathrm{a}_{\mathrm{w}}$ and moisture content in experimental samples were determined in threefold reiteration, at reliable probability $\mathrm{P}=0,95$.

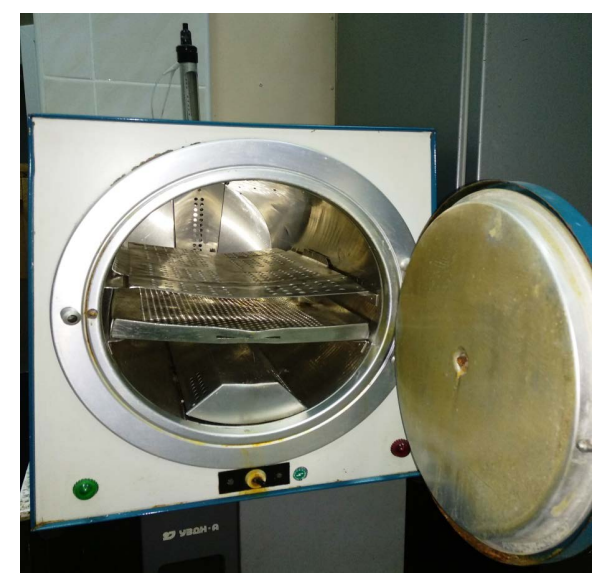

Fig. 2. Drying chamber «MLW», Germany 
The correspondence of organoleptic parameters to TC U 15.1-32122069-006:2008 requirements for wiener samples in storage terms, was determined by the five point scale [20].

\section{1. Experiments}

Packed samples of wieners were subjected to the repeated thermal processing - shortterm repeated pasteurization at temperature $85-90{ }^{\circ} \mathrm{C}$ during $20 \mathrm{~min}$ with and without using a sachet-pack of an air absorbent (Fig. 3).

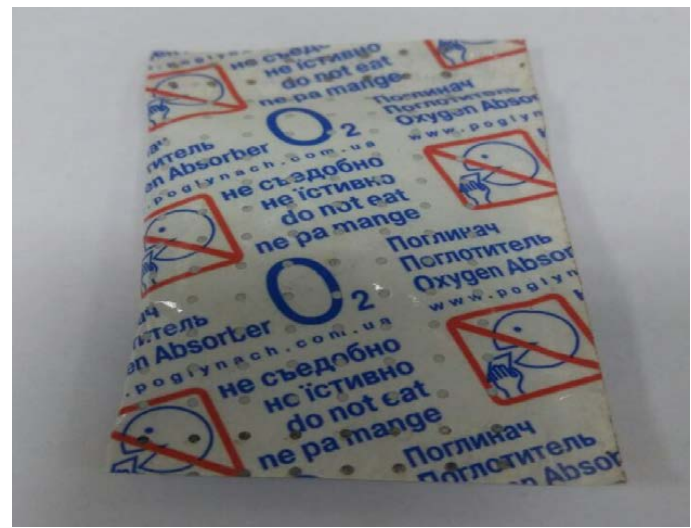

Fig. 3. Sachet-pack of an air absorber, made by "YUNAK' LTD

After repeated pasteurization packed wiener samples were cooled by washing by cold water to temperature $15^{\circ} \mathrm{C}$ with further cooling to temperature $0-6{ }^{\circ} \mathrm{C}$ for further storage.

\section{Results}

In the storage process wiener control samples determined organoleptic parameters for the first day of storage according to TC U 15.1-32122069-006:2008.

It was demonstrated on Fig. 4 that wieners of the highest sort had the average value of the point estimation by the five point scale at level 5.0, and ones of the first sort -4.88

Till 35 day inclusive (Fig. 5) the average point mark for pasteurized wieners with an air absorbent remained stable. After 35 to 94 day there took place the unessential decrease of the average point mark for these products: for wieners of the highest sort by 0,06 units, first sort - by 0,09 units (Fig. 6, 7).

The worsening of the average point mark from 35 to 94 day was up to 0.17 point units for pasteurized wieners without an air absorbent.

In whole wieners, pasteurized with and without an air absorbent at 94 day corresponded to requirements of organoleptic parameters, standardized according to TC U 15.1-32122069006:2008. At that the product preserved its outlook and dense consistence, its color was without changes.
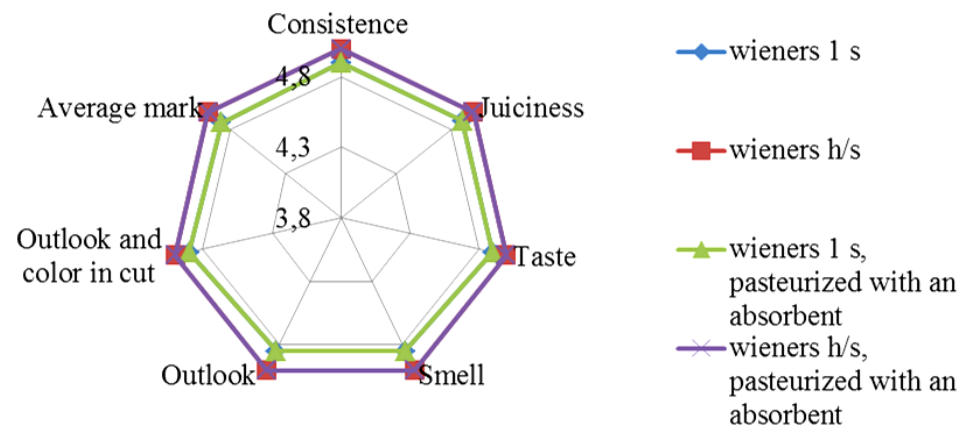

Fig. 4. Organoleptic parameters of wieners at the first storage day 


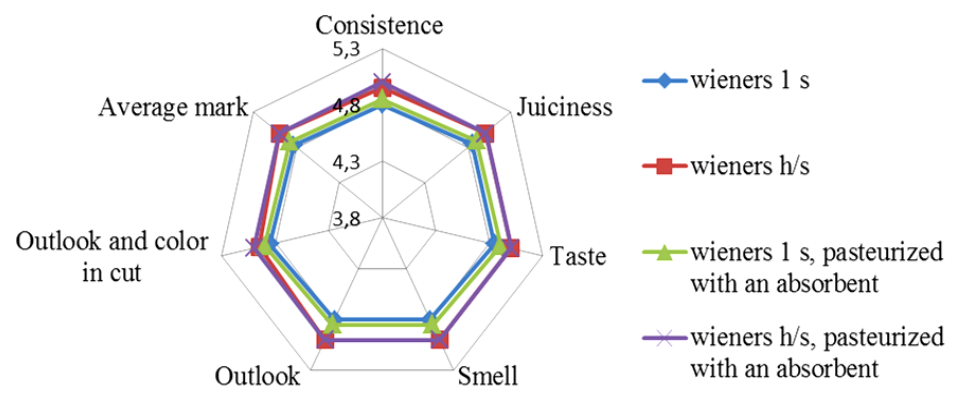

Fig. 5. Organoleptic parameters of wieners at 35 storage day

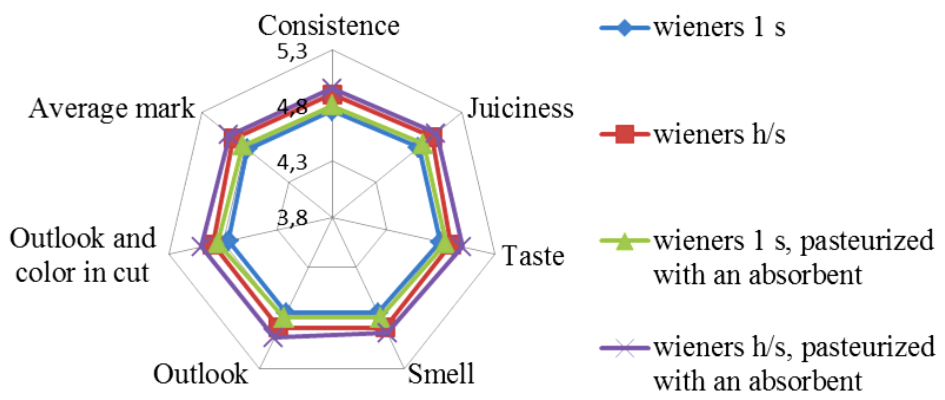

Fig. 6. Organoleptic parameters of wieners at 65 storage day

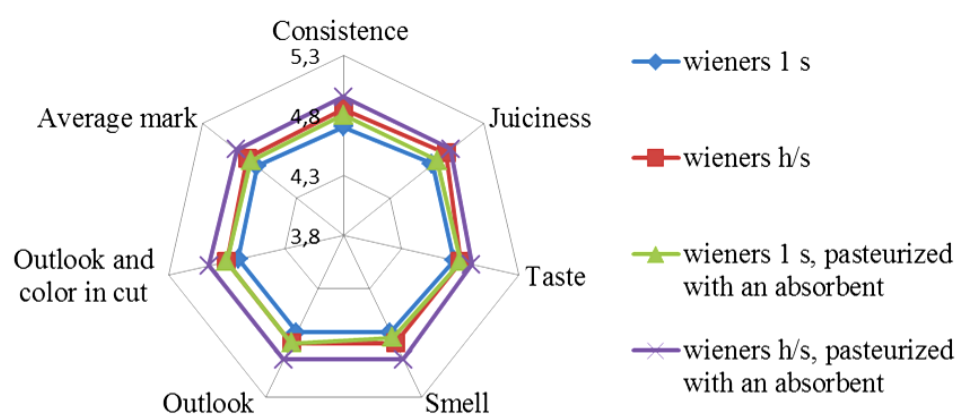

Fig. 7. Organoleptic parameters of wieners at 94 storage day

These data are coordinated with the moisture stability and $\mathrm{a}_{\mathrm{w}}$ index of sausage products at storage.

Fig. 8, 9 present the values of the water content and water activity index $a_{w}$ in samples of wieners, pasteurized with and without an air absorbent.

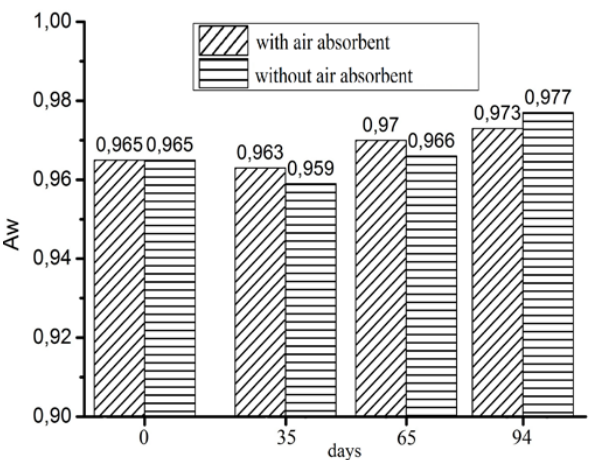

$a$

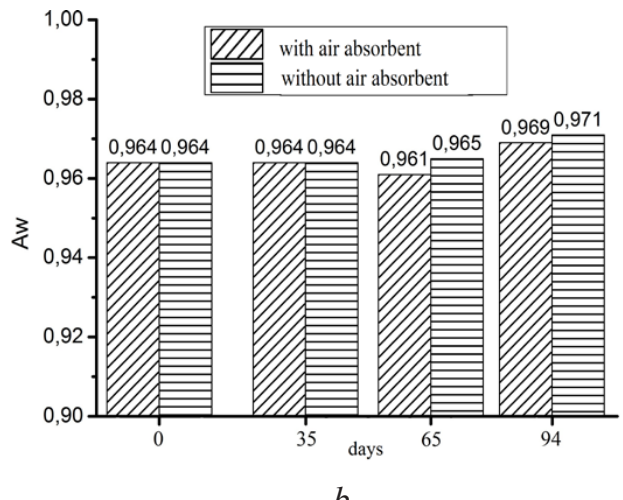

$b$

Fig. 8. Water activity indices $a_{w}$ of samples of pasteurized wieners at storage stages: $a$ - highest sort wieners; $b$ - first sort wieners 


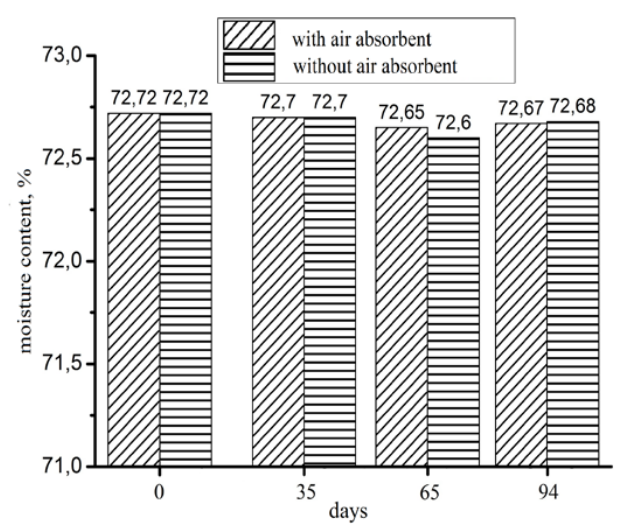

$a$

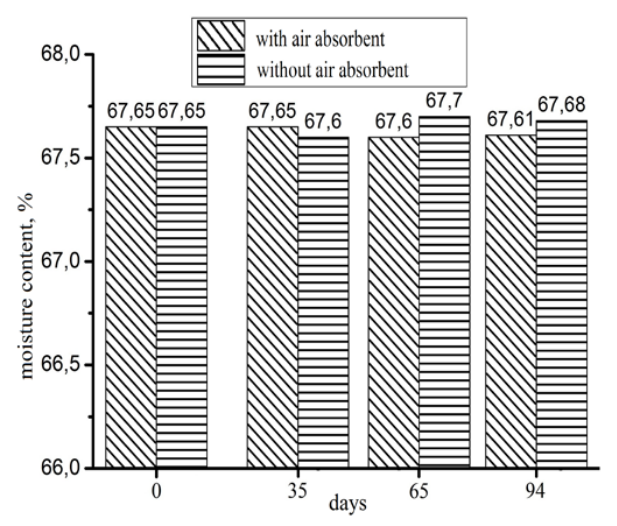

$b$

Fig. 9. Moisture content indices of samples of pasteurized wieners at storage stages: $a$ - highest sort wieners; $b$ - first sort wieners

The obtained results allow to recommend short-term repeated pasteurization together with using a sachet-pack with an air absorbent for increasing storage terms of wieners.

In the process of storage of packed pasteurized wieners of the highest sort the moisture content in samples varies within the statistical error that indicates the stability of storage conditions of experimental samples.

$\mathrm{a}_{\mathrm{w}}$ value of samples of pasteurized wieners without using an air absorbent at storage varied within 0.02 units. For pasteurized wieners with an air absorbent - within 0.01 units that indicates the unessential redistribution of bound moisture in products and is coordinated with the other determined parameters.

\section{Conclusions}

There was proved the effectiveness of repeated pasteurization of wieners with an air absorbent at temperature $85-90{ }^{\circ} \mathrm{C}$ during $15-20 \mathrm{~min}$ that allows to provide high organoleptic indices of wieners of the highest and first sorts at storage up to 94 days.

The obtained results allow to recommend repeated pasteurization together with using an air absorbent for prolonging storage terms.

It was proved that multi-layer polymer materials, produced by "Sirius Extrsion" LTD provide the high barrier of the protective package and may be used for repeated pasteurization at temperature $85-90^{\circ} \mathrm{C}$.

It was determined, that the use of packed products, pasteurized with an air absorbent in traditional conditions of storing sausage products of the boiled group at $0-6{ }^{\circ} \mathrm{C}$ allows to increase the stability of organoleptic parameters of sausages, according to normative values.

It was proved, that the use of an air absorbent at repeated pasteurization doesn't essentially influence the change of moisture of sausage products and $\mathrm{a}_{\mathrm{w}}$ value in storage terms. It proves the stability of storing conditions and grounds a possibility of prolonging the storage term up to 94 days.

Further studies will be directed on revealing the influence of repeated pasteurization with an air absorbent on the stability of fat composition indices of boiled sausages at storage.

\section{References}

[1] Dixon, J. (2011). Packaging materials: 9. Multilayer packaging for food and beverages. Commissioned by the Ilsi Europe Packaging Materials Task Force, 48. Available at: http://ilsi.eu/wp-content/uploads/ sites/3/2016/06/ILSI-11-011-9-pack-03.pdf.

[2] Vinnikova, L. G., Prokopenko, I. A. (2015). The application of high pressure as an alternative to thermal processing of poultry meat. Eastern-European Journal of Enterprise Technologies, 3 (10 (75)), 31-36. doi: https://doi.org/10.15587/1729-4061.2015.44241 .

[3] Vinnikova, L., Shlapak, H., Prokopenko, I., Hlushkov, O. (2018). Vyznachennia terminu zberihannia shynky z miasa ptytsi, vyhotovlenoi atermichnym obroblenniam. Scientific Works, 48. 
[4] Klymenko, M. M. (Ed.) (2006). Tekhnolohiya miasa ta miasnykh produktiv. Kyiv, 640.

[5] Bal-Prylypko, L. V. (2010). Tekhnolohiya zberihannia, konservuvannia ta pererobky miasa. Kyiv, 469.

[6] Pasichnyi, V., Ukrainets, A., Khrapachov, O., Marynin, A. (2018). Main aspects of using multilayer polymeric materials for pasterization and sterilization of products in the meat processing industry. Scientific Works of National University of Food Technologies, 24 (4), 195-203. doi: https://doi.org/10.24263/22252924-2018-24-4-22 .

[7] Robertson, G. L. (2012). Food Packaging: Principles and Practice. CRC Press, 733.

[8] Pasichnyi, V. M., Khrapachov, O. V., Ukrainets, A. I., Marynin, A. I., Lohvynenko, N. P., Kapitula, E. I. (2018). Use of repeated pasteurization for the production of boiled sausage products. Scientific Messenger of LNU of Veterinary Medicine and Biotechnologies, 20 (85), 29-34. doi: https://doi.org/10.15421/ nvlvet8506.

[9] LEE, J. J. (2011). Sterilization effects of avian influenza virus and newcastle disease virus in chicken muscle and organs dependent on autoclaving time. Available at: http://agris.fao.org/agris-search/ search.do? recordID=KR2012004468.

[10] Silva, F. V. M., Gibbs, P. A. (2012). Thermal pasteurization requirements for the inactivation of Salmonella in foods. Food Research International, 45 (2), 695-699. doi: https://oi.org/10.1016/ j.foodres.2011.06.018.

[11] Shahidi, F. (Ed.) (1997). Natural Antioxidants. Chemistry, Health Effects and Applications. Champaign: AOCS Press, 432.

[12] Ukrainets, A. I. (2016). Antioxidant plant extracts in the meat processing industry. Biotechnologia Acta, 9 (2), 19-27. doi: https://doi.org/10.15407/biotech9.02.019.

[13] Bal'-Prilipko, L. V., Zadorozhnyj, V. I., Onishhenko, L. V. (2006). Vliyanie razlichnyh faktorov na srok i kachestvo hraneniya mjasnyh produktov. Myasnoe delo, 8, 53-55.

[14] Ukrainets, A., Pasichniy, V., Zheludenko, Y., Zadkova, S. (2016). Oleoresins effect on cooked poultry sausages microbiological stability. Ukrainian food journal, 5 (1), 124-135.

[15] McBride, N. T. M., Hogan, S. A., Kerry, J. P. (2007). Comparative addition of rosemary extract and additives on sensory and antioxidant properties of retail packaged beef. International Journal of Food Science \& Technology, 42 (10), 1201-1207. doi: https://doi.org/10.1111/j.1365-2621.2006.01342.x .

[16] Bozhko, N., Tischenko, V., Pasichnyi, V., Marynin, A., Polumbryk, M. (2017). Study of oxidation processes in duck meat with application of rosemary and grape seed extracts. EUREKA: Life Sciences, 4, 10-15. doi: https://doi.org/10.21303/2504-5695.2017.00374

[17] Usatenko, N. F., Kryzhska, T. A. (2012). Zberihannia ta pererobka produktsiy. Vykorystannia pokaznyka «aktyvnist vody» $\mathrm{v}$ tekhnolohiyi vyrobnytstva miasoproduktiv. Visnyk ahrarnoi nauky, 5, 62-65.

[18] Benderska, O., Levkivska, T., Bessarab, A. (2018). Technological aspects of «water activity» indicator and its influence on the quality of tomato souss. International scientific journal Internauka, 2 (50), 11-14.

[19] Ustymenko, I., Korh, N., Teterina, S., Polischuk, G. (2018). Analysis of microbiological indicators of food emulsions. Scientific Works of National University of Food Technologies, 24 (2), 209-215. doi: https://doi.org/10.24263/2225-2924-2018-24-2-25 .

[20] Antipova, L. V., Glotova, I. A., Rogov, I. A. (2001). Metodyi issledovaniya myasa i myasnyih produktov. Moscow: Kolos, 576. 